\title{
THE STYGOBIONT AMPHIPODA OF JAMAICA
}

\author{
JAN H. STOCK \\ Institute of Taxonomic Zoology, University of Amsterdam, \\ P.O. Box 20125, 1000 HC Amsterdam, The Netherlands
}

\begin{abstract}
SUMMARY
Of sixty-one stygofauna samples from Jamaica, seven contained hypogean Amphipoda. These seven samples yielded four species (three new) of the genus Metaniphargus. No other genera were encountered. Descriptive notes on these four species are provided. The cladistics of Metaniphargus and allied genera are briefly discussed.

\section{RÉSUMÉ}

Parmi soixante-et-un échantillons de stygofaune de la Jamaïque, sept contenaient des Amphipodes hypogés. Ces sept échantillons ont donné quatre espèces (dont trois nouvelles) du genre Metaniphargus. D'autres genres n'ont pas été signalés. Des notes descriptives sur ces quatre espèces sont fournies. Des problèmes concernant la cladistique de Metaniphargus et des genres voisins, sont brièvement abordés.
\end{abstract}

\section{INTRODUCTION}

During the Amsterdam Expeditions to the West Indian Islands, two series of samples have been taken in groundwaters- of wells, caves, interstitia of river sands and marine sands-of Jamaica: in October 1979 in the (south)western part of the island (19 samples), and in March 1982 in the northern part (42 samples). Seven of these samples $(11 \%)$ contained blind, hypogean Amphipoda, a lower score than for instance on Curaçao, Netherlands Antilles (62 out of 94 samples, $66 \%$ ) or in the nearby Haiti ( 50 out of $229,22 \%$ ) (Stock, 1983).

The hypogean amphipod fauna in Jamaica is also taxonomically less varied than for instance in Haiti or Puerto Rico, where both "hadziids"

*) Report 32 is published in the same issue of this journal. and "weckeliids" (in the sense of Barnard \& Karaman, 1982) were found. Jamaica has yielded so far only four different species of the "hadziid" genus Metaniphargus Stephensen, 1933, a genus widely distributed with numerous endemics on the islands of the Antillean arc and the Venezuelan mainland (for a review see Stock, in press).

\section{THE JAMAICAN SPECIES OF METANIPHARGUS}

Two species groups (of the four recognized by Stock, 1977, within the genus Metaniphargus) have been found in Jamaica: the jamaicae group and the nicholsoni group.

The jamaicae group is endemic to Jamaica. In addition to the only subterranean amphipod recorded so far from the island, $M$. jamaicae (Holsinger, 1974), a new species was discovered, which makes it necessary to redefine slightly the jamaicae group, as follows:

Carpus of gnathopod 2 ( $\%$ ) elongate; palm of gnathopod 2 (ᄋ) setiferous; pleopod 3 $\left(O^{\circ}\right)$ almost without lobes; endopodite of uropod 3 long $(66-100 \%$ of the length of exopodite segment 1), armed with spines plus plumose setae.

The nicholsoni group is similar to the jamaicae group, but differs in its third uropod, the endopodite of which is shorter (less than $60 \%$ of the length of the first exopodite segment) and is devoid of plumose setae. Two new species of this group are described in this paper. 
The three new species to be described in the next pages (one of the jamaicae group, two of the nicholsoni group) differ from all Metaniphargus species described so far by the low number $(8$ or 9) of setae on the inner lobe of the first maxilla. In other species of the genus this number exceeds 15 . In this respect, the three new species resemble those of the genus Dulzura J. L. Barnard, 1969. Dulzura is, however, mainly characterized by its densely setose propodus of the male gnathopod 2, whereas the Jamaican species (at least those of which the male sex is known) have only poorly setose propodi. Moreover, all species of Metaniphargus known so far have a shortened telson (and so have the three Jamaican species), whilst those of Dulzura have a telson of ordinary length (see also Barnard \& Karaman, 1982, key on p. 178). It should be noted that Barnard \& Karaman attribute medial telson spines to Metaniphargus (such spines being absent in Dulzura), but that such spines are lacking in several Metaniphargus species, in particular of the nicholsoni group.

\section{KEY TO THE JAMAICAN SPECIES OF THE GENUS METANIPHARGUS}

1a) Length of endopodite of uropod 3 from 66 to $100 \%$ of that of the first segment of the exopodite; armed with spines plus plumose setae. Claw of the posterior pereiopods with additional setae on its posterior margin ........................................... 2

b) Endopodite of uropod 3 less than $60 \%$ of the length of exopodite segment 1 ; armed with spines only. Claw of the posterior pereiopods lacking additional setae............ 3 2a) Endopodite of uropod 3 about $2 / 3$ as long as exopodite segment 1. Telson halves with (sub)distal spines only. Inner lobe of maxilla 1 with 8 or 9 setae. Posterodistal corner of basis of $\mathrm{P} 5-\mathrm{P} 7$ rounded, not produced into a triangular point. $M$ craterensis n. sp. (freshwater spring, Parish of St. Ann)

b) Endopodite of uropod 3 at least $4 / 5$ as long as exopodite segment 1 . Telson halves with distal and medial spines. Inner lobe of maxilla 1 with more than 15 setae. Posterolateral corner of basis of P5-P7 produced into a triangular projection. ........... jamaicae (Holsinger, 1974) (mixohaline cave- and well waters, Parish of Clarendon) 3a) Second exopodal segment of uropod 3 almost half as long as first segment; the latter devoid of plumose setae.
Palmar margin of gnathopod $2\left(\sigma^{*}\right)$ with spines of a size. M. anchihalinus n. sp. (anchihaline clefts in limestone terrace, Parish of St. Ann) b) Second exopodal segment of uropod $3<50 \%$ of the first segment; the latter provided with some plumose setae. Palmar margin of gnathopod $2\left(\sigma^{\circ}\right)$ with spines of irregular size.

M. hyporheicus n. sp. (in coarse sediments near mouth of streams, Parishes of St. Ann and Hanover).

Metaniphargus jamaicae (Holsinger, 1974). Fig. 1.

Refs. - See Stock, 1977: 65-67, figs. 43-45.

Material. - More than 100 specimens. Amsterdam Expeditions to the West Indian Islands, sta. 79-43: Jamaica, Parish of Clarendon, Jackson Bay Cave $\left(17^{\circ} 43^{\prime} 55^{\prime \prime} \mathrm{N}\right.$ $\left.77^{\circ} 13^{\prime} 43^{\prime \prime} \mathrm{W}\right)$, in stagnant waters filling great parts of a huge cave system (both in semi-darkness and completely dark); handnet; water depth 30-60 cm; chlorinity 2028 mg/l; 24 Oct. 1979 (ZMA coll. no. Amph. 107.646). Accompanying fauna: Polychaeta, Pyrgophorus (Gastropoda), Mysidacea (2 spec.), Cardiosoma (Decapoda Brachyura), Cyclopoidea.

One $\%$, ditto, sta. 79-45: Jamaica, Parish of Clarendon, Milk Spring (Wilco Factory), near Springfield $\left(17^{\circ} 51^{\prime} 46^{\prime \prime} \mathrm{N} 77^{\circ} 20^{\prime} 36^{\prime \prime} \mathrm{W}\right.$ ); deep well (diameter $60 \mathrm{~cm}$, water level at $25 \mathrm{~m}$, water depth $33 \mathrm{~m}$ ); Cvetkov net; water temperature $25.8^{\circ} \mathrm{C}$; chlorinity $134 \mathrm{mg} / \mathrm{l}$; 24 Oct. 1979 (ZMA Amph. 107.647). Accompanying fauna: Mysidacea, Cyclopoidea, Oligochaeta.

Remarks. - The specimens from station 79-43 are topotypes. Up to now, the species was never recorded outside the type-locality. The single female caught at station 79-45 thus constitutes a second locality for this species.

An almost complete description is found in the papers of Holsinger (1974) and Stock (1977). The endopodite of the third uropod varies slightly in length. In full-grown specimens, its length can fluctuate from 90 to $100 \%$ of the length of the first exopodite segment. In juveniles (of less than $2 \mathrm{~mm}$ in body length) the length of the inner ramus ranges from 80 to $90 \%$ of that of segment 1 of the exopodite (fig. 1e).

The morphology of the juveniles is of some importance, since several "juvenile characters" are found back in $M$. craterensis, to be described in the sequel. The number of D-setae on the 


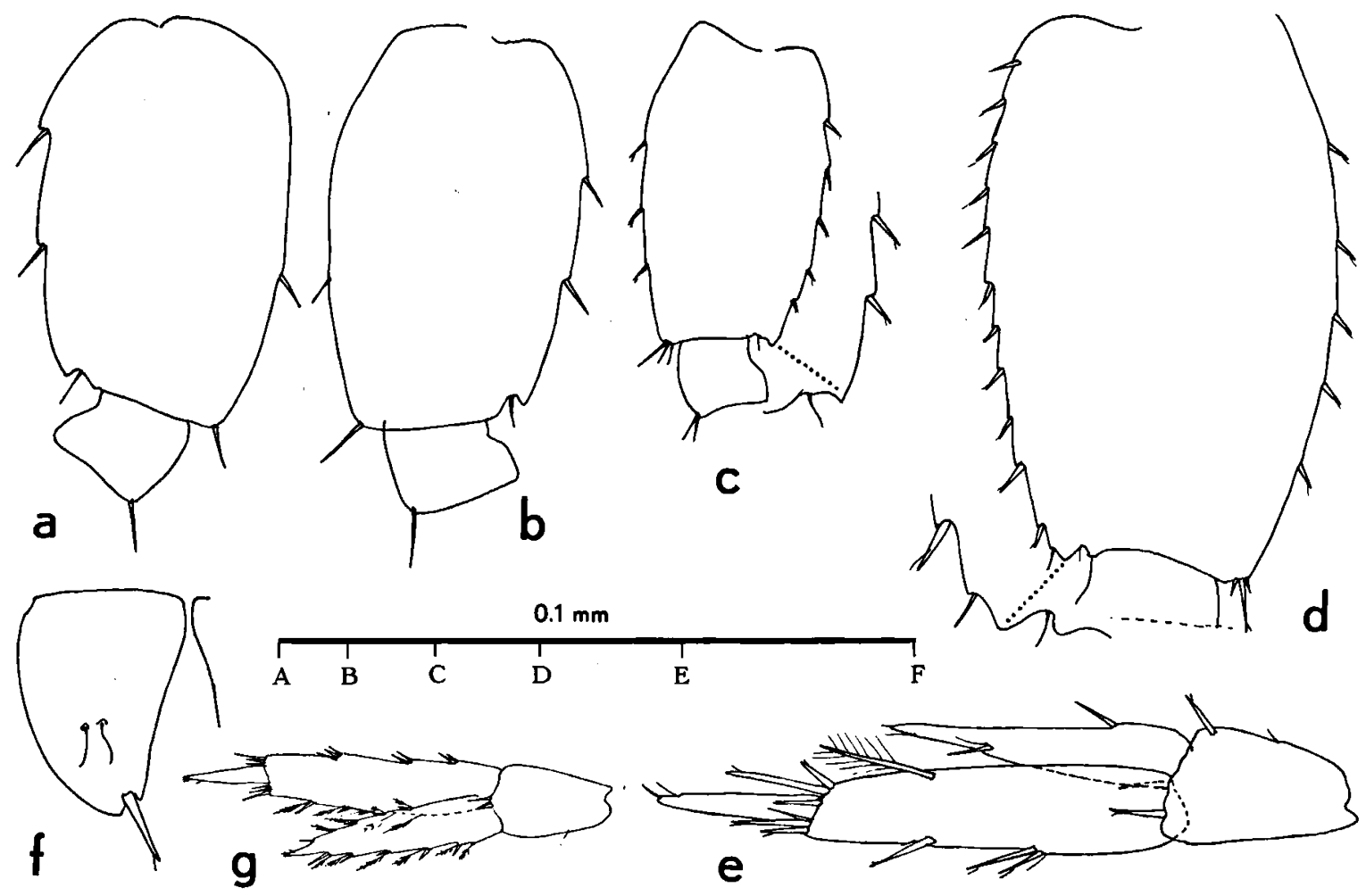

Fig. 1. Metaniphargus jamaicae (Holsinger, 1974) (sta. 79-43): a, proximal segments of sixth pereiopod of a juvenile (body length < $2 \mathrm{~mm}$ ) (scale $A C$ ); $b$, ditto of seventh pereiopod of same juvenile (AC); $c$, ditto of seventh pereiopod of a young female (body length $2.5 \mathrm{~mm}$ ) (AB); d, ditto of the seventh pereiopod of an adult female (body length $3.5 \mathrm{~mm}$ ) (AB); e, third uropod of a juvenile (body length $<2 \mathrm{~mm}$ ) (AC); f, telson of the same juvenile (AD); $\mathrm{g}$, third uropod of adult female (AB).

ventral margin of mandible palp segment 3 is lower than in adults. The number of setae on the inner lobe of maxilla 1 is 9 or 10 , thus distinctly lower than in adults. The telson bears only 1 (rarely 2) distal spines and is still devoid of medial spines. However, even in small juveniles, the basis of pereiopods 5 to 7 already shows the characteristic morphology of the posterodistal corner, marked by an unarmed, triangular, produced lobe, on the median side of which a setule is implanted in the centre of a rounded sinus (figs. 1 a-d). The number of spinules on both the anterior and posterior margins of the basis in P5-P7 increases with age.

The gland cone on antenna 2 is correctly illustrated by Holsinger (1974, fig. 3b). It is regularly conical and rather robust. The entire cone (and not just the distal tubiform part) tends to point obliquely downward.

\section{Metaniphargus craterensis n. sp. Figs. 2-3.}

Material. - One $\odot$ (holotype), one $\odot$ and three juveniles (paratypes). Amsterdam Expeditions to the West Indian Islands, sta. 82-137: Jamaica, Parish of St. Ann, small spring on the south shore of Crater Lake, E. of the village of Discovery Bay and just $E$. of the drinking water pumping station $\left(18^{\circ} 27^{\prime} 23^{\prime \prime} \mathrm{N} 77^{\circ} 22^{\prime} 56^{\prime \prime} \mathrm{W}\right)$; the spring opens through a deep $(>150 \mathrm{~cm})$ tubular outflow of about $10 \mathrm{~cm}$ in diameter in a gravelly substrate; it is fast-flowing and fresh (chlorinity $40 \mathrm{mg} / \mathrm{l}$ ); temperature $22.0^{\circ} \mathrm{C} ; 28$ March 1982 (ZMA Amph. 107.648a, b). Accompanying fauna: Planaria, Oligochaeta, Pyrgophorus (Gastropoda), Bivalvia Pisidiidae, Macrura, Trichoptera larvae.

Description. - Female: Body length 2.5-3.0 $\mathrm{mm}$. Blind, unpigmented. Urosomite 1 with 2 
dorsal spines, urosomite 2 with 3 dorsal spines (fig. 3d).

First antenna (fig. 2a) somewhat less long than the body. Peduncle segment 1 with 2 ventral spines; segment 2 shorter than segment 1 ; segment 3 half as long as segment 2. Accessory flagellum (fig. 2b) slightly more than half as long as flagellum segment 1, 2-segmented, armed with $1+3$ short setae. Flagellum 12-segmented; one aesthetask is found on segments 8 and 9, two aesthetasks on segment 11; these aesthetasks are slightly shorter than the segment on which they are implanted.

Second antenna (fig. 2c) with a heavy, short, conically rounded gland cone. Flagellum 8-segmented. The entire appendage is sparsely armed with short setae only.

Labrum as in $M$. curasavicus curasavicus (see Stock, 1977, fig. 7e).

Mandible: Masticatory part as in $M$. hyporheicus (vide infra). Palp (fig. 2d) with unarmed 1st and 2nd segments; segment 3 the longest, armed with 4 stiff setules of a size in the distal part of its ventral margin, and with 3 longer distal setae.

Labium (fig. 2l) without well-developed inner lobes.

First maxilla (figs. 2e, f, g) with asymmetrical palps, the left one being more slender; the 5 distal elements on the left palp are also more slender than those on the right palp. Outer lobe with 11 distal spines, whose medial margin bears a varying number of denticles; from lateral to medial, these spines bear 2, 2, 3, 4, 4, $4,4,5,5,7$ and 9 denticles, respectively. Inner lobe slender, tapering, armed with 9 plumose setae.

Second maxilla and maxilliped similar to those of $M$. c. curasavicus.

First gnathopod (fig. 2h) characterized by a very elongate carpus, the posterior margin of which bears 3 groups of setae. Propodus (fig. 2i) also rather elongate; its posterior margin bears 1 group of setae only. Palmar corner with 5 bifid spines: 3 shorter and 2 longer ones; the anterior cusp of the longer spines is larger than the posterior cusp (fig. $2 \mathrm{i}$, detail).

Second gnathopod (fig. 2j): Basal segments as in $M$. hyporheicus (vide infra). Carpus with 5 groups of setae on its posterior margin, propodus with 2 such groups. Palmar corner marked by 2 simple spines. Propodus rather narrow in shape.

Coxal gills as in $M$. hyporheicus. Oöstegites linear, non-setose in the holotype (nonreproductive or subadult phase).

Third and fourth (fig. 2k) pereiopods similar. Coxal plate not longer than wide.

Fifth pereiopod (fig. 3a) with rather narrow basal segment; its posterior margin is armed with 5 short, setiform elements; posterodistal corner marked by a slight notch in which a setule is implanted. Posterior margin of merus unarmed; very sparse armature on carpus and propodus. Claw slender with 1 plumose subbasal seta, 2 normal setae near the implantation of the ungulus, and 2 extra setae in its distal half.

Sixth pereiopod also characterized by reduced armature (fig. $3 \mathrm{~b}$ ). Posterior margin of basis armed with 3 to 5 short setiform elements; posterodistal corner rounded, with a notch in which a setule is implanted. Claw (fig. 3b, detail) slender, with 1 extra seta on its posterior margin.

Seventh pereiopod (fig. 3c): Basis with slightly convex posterior margin, armed with 7 short setiform elements; posterodistal corner resembling that of P5 and P6 (fig. 3c, detail). Distal leg segments lacking in all specimens examined.

Epimeral plates (fig. 3e) with rectangular posterior corners.

Uropod 1 with slender rami (fig. 3f); both exo- and endopodite armed with 2 dorsal spines.

Uropod 2 (fig. 3g): Pedunculus with distal row of 3 or 4 spinules, in addition to 2 larger spines. Exopodite with 1 strong dorsal spine, endopodite with 2 such spines.

Uropod 3 (fig. 3h): Exopodite 2-segmented; second segment finger-shaped, longer than the distal spines on the top of segment 1. Endopodite about $2 / 3$ of the length of exopodite segment 1; inner margin with 3 spines and 1 plumose seta; tip pointed, with 2 setules; outer margin with 1 spine. 


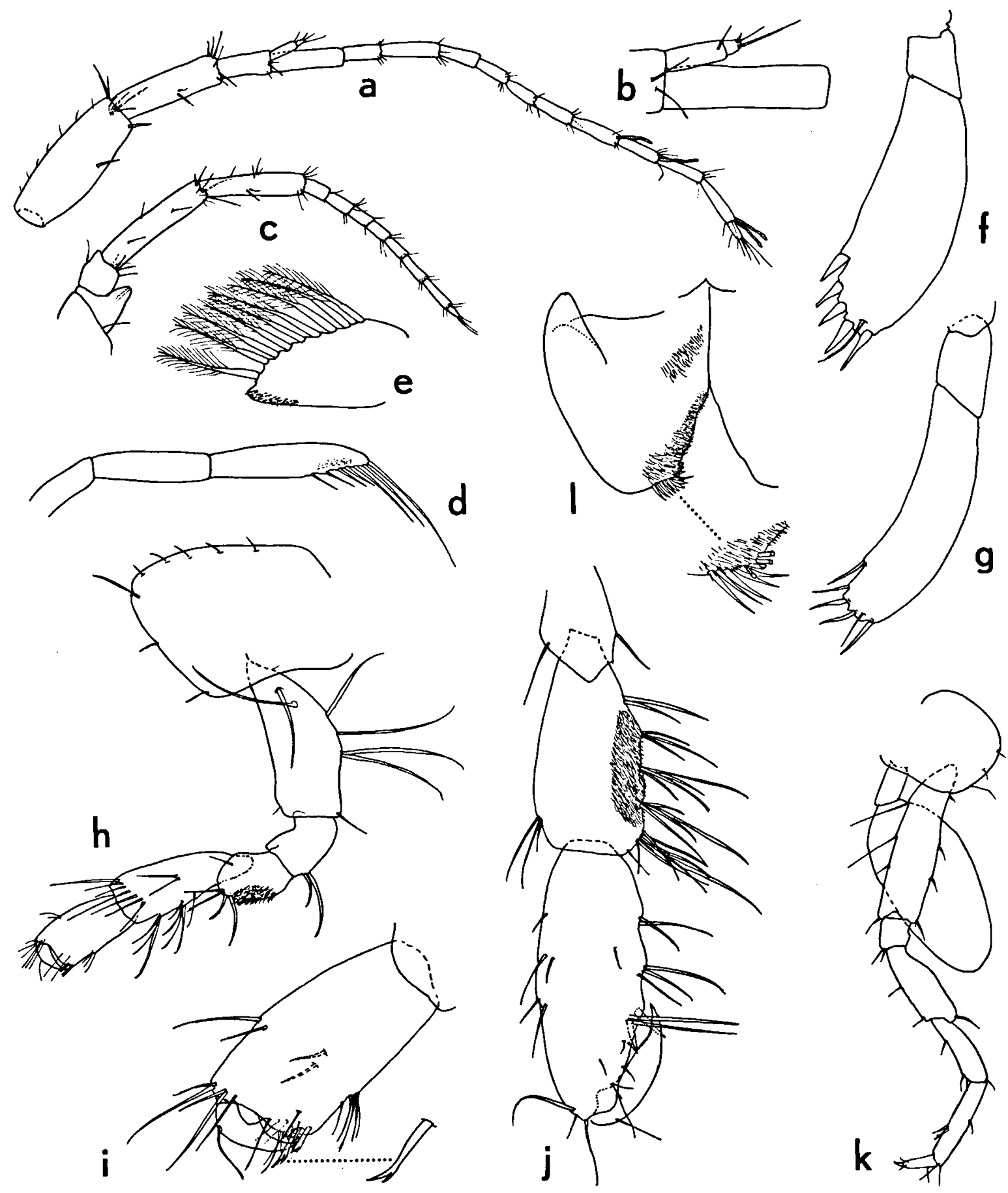

Fig. 2. Metaniphargus craterensis n. sp. ( $९$ holotype; sta. 82-137): a, first antenna (scale AB); b, accessory flagellum of first antenna (AC); $c$, second antenna (AB); d, mandible palp (AC); e, inner lobe of first maxilla (AD); $f$, palp of right first maxilla (AD); $g$, palp of left first maxilla (AD); $h$, first gnathopod (AB); i, propodus of first gnathopod (AD); j, distal segments of second gnathopod (AC); k, fourth pereiopod (AB); l, labium (AB). Scales: see fig. 1. 


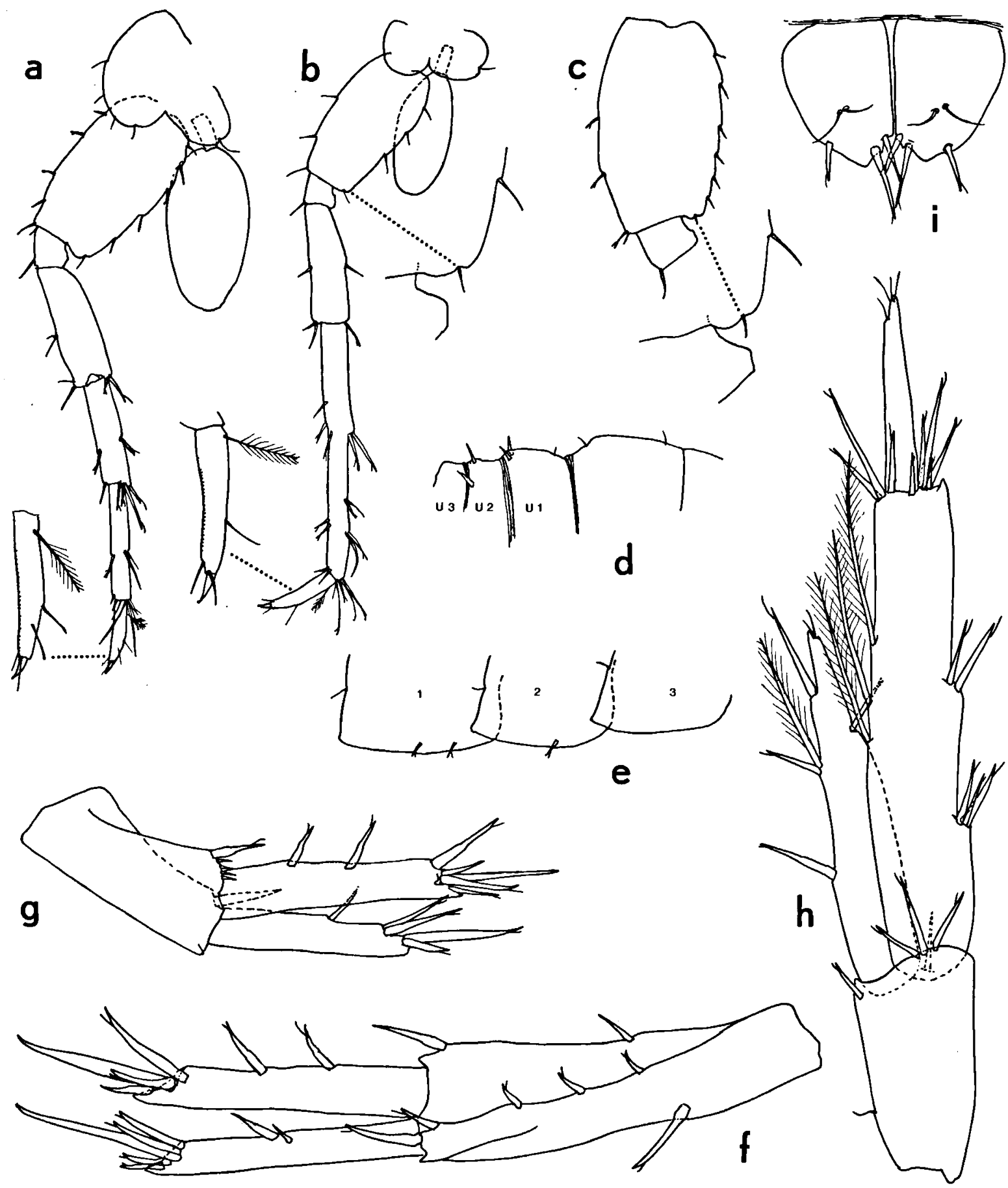

Fig. 3. Metaniphargus craterensis $\mathrm{n}$. sp. ( $\%$ holotype, except for $3 \mathrm{~b}$ which is after a juvenile female paratype; sta. 82-137): a, fifth pereiopod (scale $A B$ ); b, sixth pereiopod (AB); c, seventh pereiopod (AB); d, contour of urosome, from the right (AB); e, epimeral plates 1 to 3 (AB); f, first uropod (AC); g, second uropod (AC); h, third uropod (AC); i, telson (AC). Scales: see fig. 1. 
Telson (fig. 3i) short, broad, entirely cleft, armed with 1 laterodistal and 2 mediodistal spines.

Remarks. - $M$. craterensis belongs to the jamaicae group within the genus Metaniphargus, as redefined above. Although the male of $M$. craterensis is unknown (and hence the secondary sexual dimorphism in the 3rd pleopod remains unknown), the all-over similarity to $M$. jamaicae is striking. So, the posterior margin of the claws of pereiopods 5 to 7 bears additional setae in both $M$. jamaicae and $M$. craterensis; such setae are not known from other species in the genus.

Differences from adult $M$. jamaicae are found in the number of setae on the inner lobe of maxilla 1 (8-9 in craterensis, $>15$ in jamaicae), the unarmed 2nd mandible palp segment, the low number of $\mathrm{D}$-setae on the 3rd mandible palp segment, the shorter endopodite of uropod 3 , the absence of medial spines on the telson lobes, the presence of setules (not spinules) on the posterior margin of the basis of pereiopods 5 to 7 , etc.

Many of these characters are typical, however, of juvenile $M$. jamaicae. From such juveniles, $M$. craterensis can be distinguished by a still shorter endopodite of uropod 3 (66\% of the length of the first exopodite segment in craterensis, $80-90 \%$ in juvenile $M$. jamaicae), more distal spines on the telson lobes (3 in craterensis, 1 to 2 in juvenile jamaicae), and in the outline of the basis of the posterior pereiopods (with 2 rounded lobes in craterensis, with one produced, triangular lobe in jamaicae).

Habitat. $-M$. craterensis is also ecologically different from the other Metaniphargus species described so far (with the exception perhaps of M. bousfieldi Stock, 1977, from Puerto Rico), in that it lives in entirely fresh waters, and not in mixohaline conditions. Together with certain taxa from the Leeward group of the Netherlands Antilles ( $M$. curasavicus curasavicus Stephensen, 1933; $M$. longipes longipes Stock, 1977 , etc.), it is one of the few species known to live in running waters.
Metaniphargus hyporheicus n. sp. Figs. 4-7.

Material. - One $\sigma^{\prime}$ (holotype), one \& (allotype), three $९$, two juvs., and three fragmentary specimens (paratypes). Amsterdam Expeditions to the West Indian Islands, sta. 82-134: Jamaica, Parish of St. Ann, Discovery Bay, mouth of the Rio Secco, about $15 \mathrm{~m}$ from the sea $\left(18^{\circ} 27^{\prime} 21^{\prime \prime} \mathrm{N} \quad 77^{\circ} 24^{\prime} 34^{\prime \prime} \mathrm{W}\right)$. Dry riverbed; method Karaman-Chappuis in coarse gravel and boulders, very little sand; $150 \mathrm{l}$ of interstitial water filtered; chlorinity $26,580 \mathrm{mg} / \mathrm{l}$; temperature $25.8^{\circ} \mathrm{C}$; 28 March 1982 (ZMA Amph. 107.641 a-c). Accompanying fauna: Cirolanidae (Isopoda).

Three $९$ ९, one juv., sta. 82-138: As sta. 82-134, but ca. $25 \mathrm{~m}$ from the sea; chlorinity $5228 \mathrm{mg} / \mathrm{l}$; temperature $26.2^{\circ} \mathrm{C} ; 100 \mathrm{l}$ of water filtered; 29 March 1982 (ZMA Amph. 107.644). Accompanying fauna: Polychaeta, Cirolanidae, Microcerberidae (Isopoda).

Three $Q$ Q, sta. 82-136. As sta. 82-134, but ca. $35 \mathrm{~m}$ from the sea; chlorinity $4848 \mathrm{mg} / \mathrm{l}$; temperature $25.8^{\circ} \mathrm{C}$; $150 \mathrm{l}$ of water filtered; 28 March 1982 (ZMA Amph. 107.643). Accompanying fauna: Nematoda, Oligochaeta, Ostracoda, Cirolanidae, Collembola.

Three $९$ \%, sta. 82-112: Jamaica, Parish of Hanover, nameless brooklet between Flint and Great Rivers, near hamlet of Orchard $\left(18^{\circ} 26^{\prime} 57^{\prime \prime} \mathrm{N} 78^{\circ} 02^{\prime} 57^{\prime \prime} \mathrm{W}\right)$; mouth of the small brooklet on the beach, about $5 \mathrm{~m}$ from the sea, in coarse sand mixed with some gravel; method KaramanChappuis; chlorinity $74 \mathrm{mg} / 1$; temperature $26.0^{\circ} \mathrm{C}$; 20 March 1982 (ZMA Amph. 107.642). Accompanying fauna: Collembola, depigmented Asellota (Isopoda), div. sp. Diptera larvae, div. sp. Gastropoda.

Description. - Body length (without antennae and uropods) 2.5-3.0 mm. Blind, unpigmented. Cephalosome, metasomites, and pleonites with isolated dorsal cilia; urosomites 1 and 2 with a pair of dorsal spines.

Head lobes (fig. 4a) rounded; antennal sinus very shallow.

First antenna (figs. 4b, c) slightly shorter than the body. Pedunculus 3-segmented; segment 1 with 2 or 3 ventral spines, segment 2 slightly shorter than segment 1 ; segment 3 half as long as segment 2. Accessory flagellum (fig. 4d) slightly shorter than flagellum segment 1 , 2 -segmented. Flagellum slender, elongate, 20to 31 -segmented, armed with short setae; basal 12 segments without aesthetask, others (except for the terminal segment) with an aethetask which is longer than half the length of the corresponding segment.

Second antenna (fig. 4e) much shorter than the first. The gland cone is as long as segment 


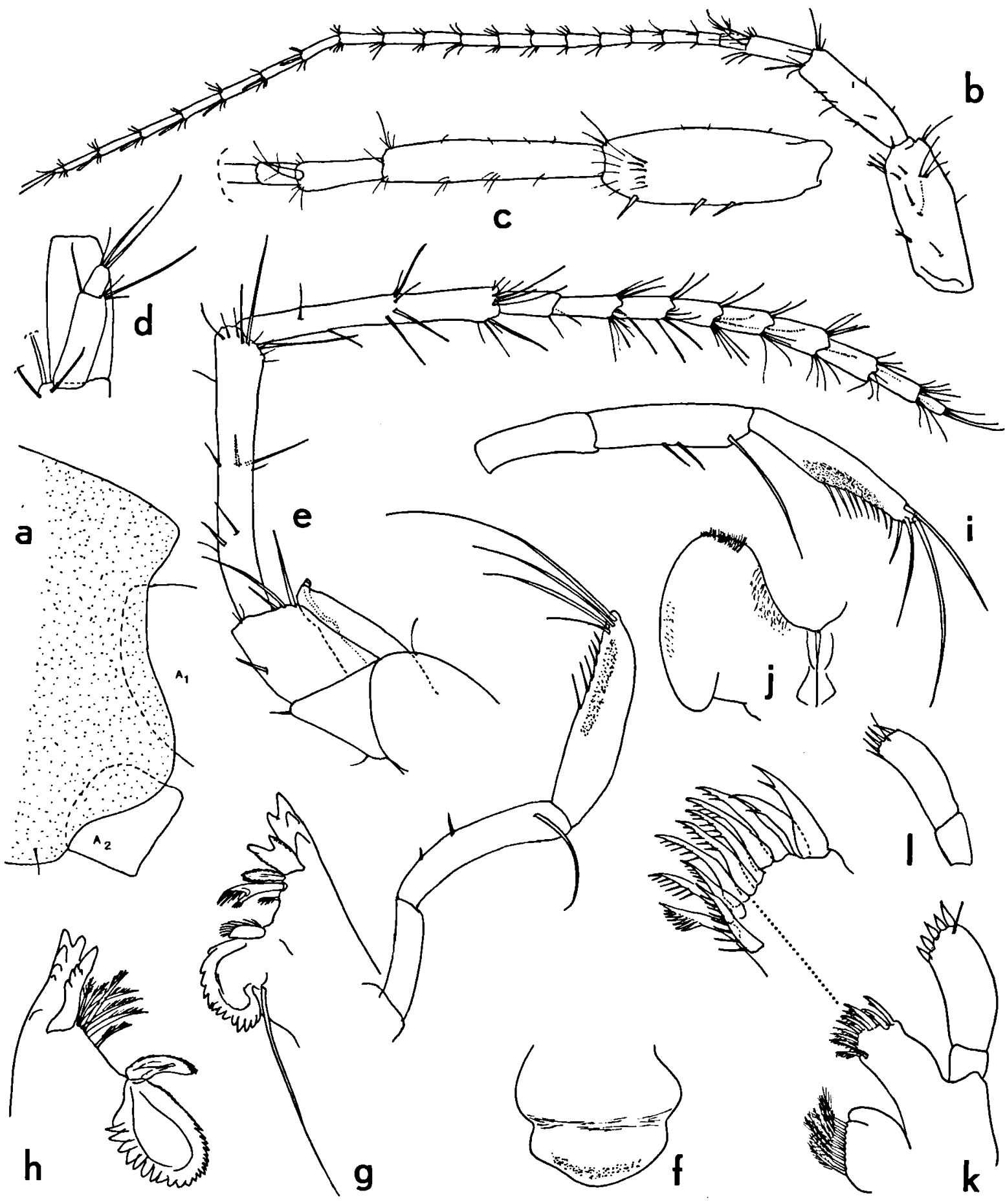

Fig. 4. Metaniphargus hyporheicus n. sp. ( $\odot$ from sta. 82-112, and $\sigma^{*}$ from sta. 82-134): a, cephalic somite, from the left, $\$$ (scale AC); b, first antenna, $\$$ (AB); c, basal portion of first antenna, $\sigma^{\circ}(\mathrm{AB})$; d, accessory flagellum, 우 (AC); e, second antenna, $Q$ (AC); f, labrum, $Q$ (AC); $g$, right mandible, $\&$ (AD); h, masticatory part of left mandible, $\$$ (AD); i, mandible palp, $\sigma^{\circ}(A C) ; j$, labium, $Q$ (AC); $k$, right first maxilla, $Q$ (AC); l, palp of left first maxilla, $Q$ (AC). (A,$A_{2}$ = implantation of first and second antenna.) Scales: see fig. 1 . 
4, and discharges through a short distal tube pointing downward. Segments 4 and 5 very long and slender, armed with several longer and shorter setae. Flagellum 9- to 12-segmented.

Labrum (fig. 4f) of the usual shape.

Mandibles asymmetrical. The right mandible (fig. $4 \mathrm{~g}$ ) has a bifid, finely toothed, lacinia mobilis, followed proximad by a leaf-like spine, a bicuspidate spine and a short plumose element; pars molaris with a long seta. Left mandible (fig. $4 \mathrm{~h}$ ) with a robust lacinia mobilis, armed with 3 lateral teeth, followed proximad by 7 plumose setae; pars molaris devoid of a seta. Left and right palps similar (fig. 4i): basal segment much longer than wide; second and third segments subequal; segment 2 with 1 or 2 midventral and 1 distal setae; segment 3 straight, with a row of 9 D-setae, regularly decreasing in size from proximal to distal, and 4 E-setae.

Labium (fig. 4j) without clearly demarcated inner lobes.

First maxilla (fig. 4k): Inner lobe wide, rounded, armed with 8 to 11 distal setae. Outer lobe with 11 teeth; these teeth bear from the inner to the outer side, $8,7,6,5,5,5,5,4,2$, 1 , and 1 median denticles, respectively. Palp 2-segmented, asymmetrical: left palp more slender than the right one; left palp (fig. 4l) armed with 5 slender distal spines and 1 distal seta; right palp (fig. $4 \mathrm{k}$ ) with 5 robust distal spines and 1 distal seta.

Second maxilla (fig. 5a) of the usual structure. Outer lobe with 2 rows of setae of 9 and 4 elements each. Inner lobe with 7 distal setae, an oblique row of 9 setae, and 3 medial setae.

Maxilliped (fig. 5b) in general shape and armature similar to that of the type-species of the genus, M. c. curasavicus Stephensen, 1933. Inner lobe with 1 medial and 3 distal elements; an extra, denticulated, distal element appears to be characteristic of this species.

The first gnathopod is in younger specimens (fig. 5c) rather similar to that of $M . c$. curasavicus; the carpus bears 3 groups of setae on its posterior margin and 2 groups of setae on the propodus (fig. 5d); carpus and propodus are ovate to rectangular in shape. In older specimens (fig. 5e) the carpus and propodus are more elongate in shape; the carpus bears 4 groups and the propodus 3 groups of setae on its posterior margin. The palmar corner (figs. $5 \mathrm{~d}$, e, detail) is marked by 5 bifid spines; the two distal cusps of these spines are subequal in size, or the anterior cusp is overreaching the posterior one.

The second gnathopod has a sexually dimorphic propodus. In the female (fig. 6a) carpus and propodus are subequal in length. The carpus bears 6 groups of setae on its posterior margin. The propodus is ovate; its posterior margin is armed with 3 groups of setae; the palmar corner is provided with 2 spines and 3 long setae; the palmar margin is short and is armed with 3 setules only. Claw short. In the male (fig. 5f) the propodus is more elongate in shape and is much longer than the carpus. The morphology of the carpus is similar to that of the female. The propodus bears, as in the female, 3 groups of setae on its posterior margin, but the palmar corner is marked by 1 longer and 2 shorter spines, and 1 long seta, whereas the long palmar margin is armed with 2 rows of spines of rather irregular size. The claw is long.

Coxal gills on P2 through P6, with a long and well-demarcated basal stalk (fig. 6b); gills largest on the anterior legs, smaller on the posterior ones. Oöstegites (fig. 6c) linear, on legs 2 through 5.

Third pereiopod similar to the fourth (fig. $6 d$ ). Third and fourth coxal plates (figs. 6b, d) about as long as wide, the latter without posterior emargination.

Fifth pereiopod (figs. 6e, $\mathrm{f}$ ) shorter than the sixth, not extremely slender; basal segment with convex to straight posterior margin, armed with 9 to 11 (in juveniles less) short, spiniform elements; its posterodistal corner is marked by a small tooth.

Sixth pereiopod similar to the fifth (figs. 7a, b).

Seventh pereiopod (figs. 7c, d) hardly longer than the sixth; posterior margin of the basal segment slightly convex to nearly straight (in 


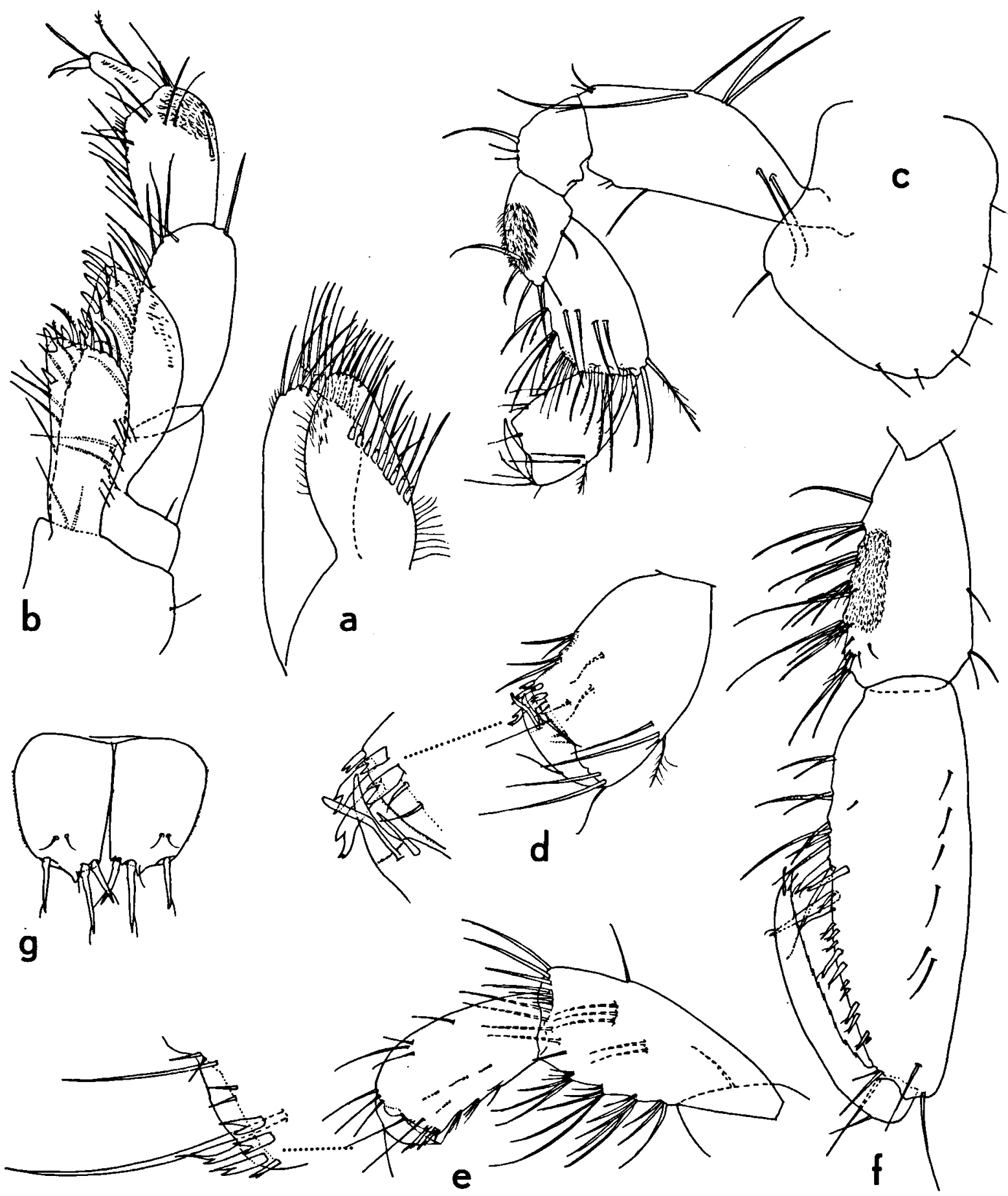

Fig. 5. Metaniphargus hyporheicus n. sp. ( $\odot$ from sta. 82-112, 0 from sta. 82-137): a, second maxilla, $९$ (scale AD); b, maxilliped, $Q$ (AD); c, first gnathopod, $\$$ (AC); d, propodus of first gnathopod, $\$$ (AD), and its palmar margin more strongly magnified (AF); e, distal segments of first gnathopod, $\sigma^{\circ}(\mathrm{AC})$, and its palmar corner more strongly magnified (AE); f, distal segments of second gnathopod, ơ (AC); g, telson, $९$ (AC). Scales: fig. 1. 


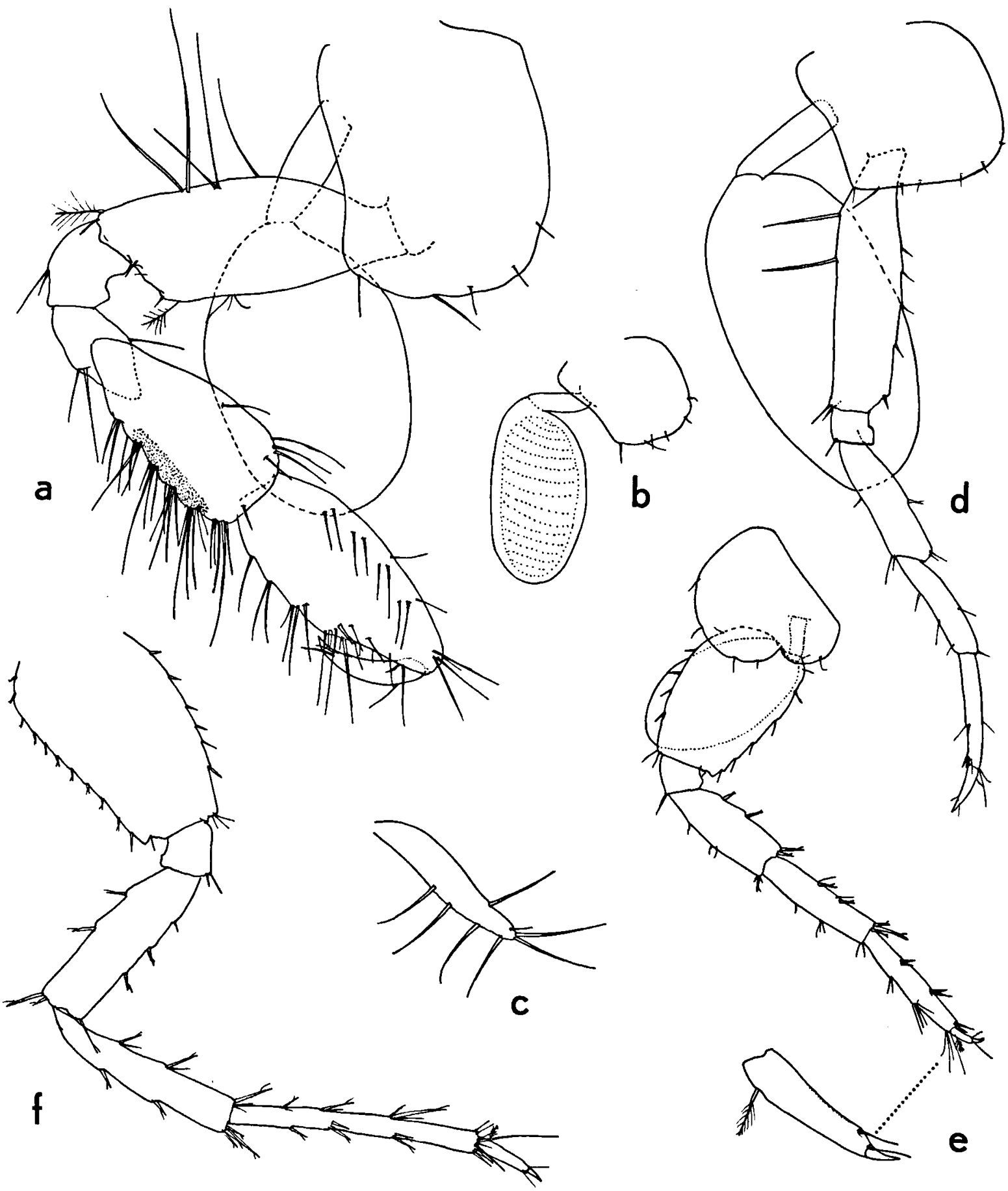

Fig. 6. Metaniphargus hyporheicus n. sp. (a, b, e: $\$$ from sta. 82-112; c, d: $Q$ from sta. 82-134; f: ${ }^{\circ}$ from sta. 82-134): a, second gnathopod, $Q$ (scale AC); b, coxal plate and coxal gill of third pereiopod, $Q$ (AB); c, oöstegite of second pereiopod, $\$(\mathrm{AB})$; d, fourth pereiopod, $Q$ (AB); e, fifth pereiopod, $Q$ (AB); f, fifth pereiopod, $\sigma^{\circ}(\mathrm{AB})$. Scales: see fig. 1 . 


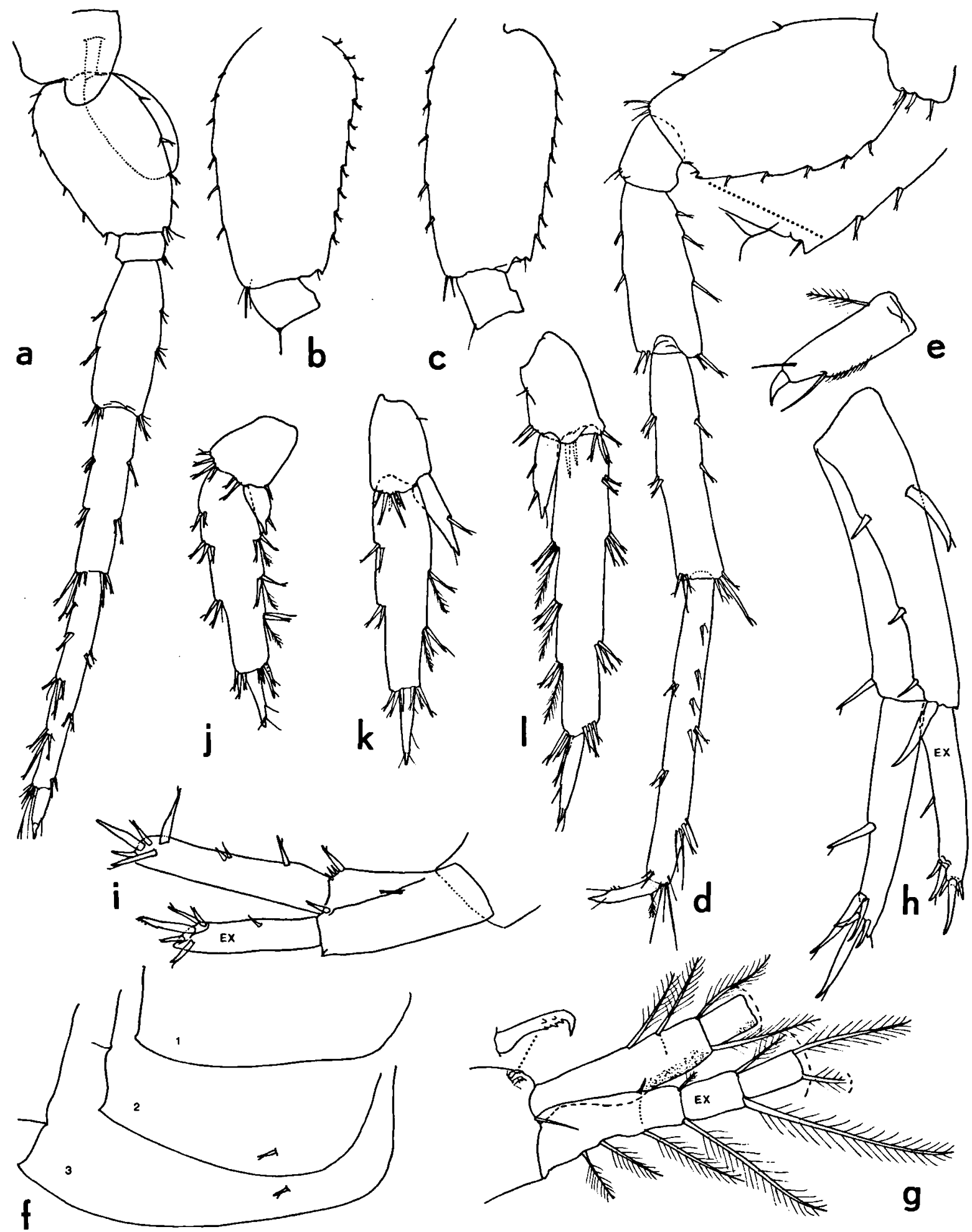

Fig. 7. Metaniphargus hyporheicus n. sp. (a, e, f, h, i, j: @ from sta. 82-112; b, c, g, l: ơ from sta. 82-134; d, k: $ᄋ$ from sta. 82-134): a, sixth pereiopod, $\$$ (scale AB); b, basis of sixth pereiopod, $O^{\circ}(A B) ; c$, basis of seventh pereiopod, $0^{\circ}(A B) ; d$, seventh pereiopod, $\$$ (AB); e, claw of seventh pereiopod, $Q$ (AD); f, epimeral plates 1 to $3, Q$ (AC); $\mathrm{g}$, third pleopod, $\sigma$ (distal part of the rami omitted) (AC); h, first uropod, $\$$ (AC); i, second uropod, $\$$ (AC); j, third uropod, $९$ (AB); $k$, third uropod, ${ }^{\prime \prime}(\mathrm{AB})$; 1 , third uropod, $\mathrm{O}^{\prime}(\mathrm{AB})$. Scales: see fig. 1. 
older specimens), armed with 5 to 8 short spiniform elements; its posterodistal corner is marked by a small tooth.

Pleopods without particularities; each with 2 retinacula. The third male pleopod (fig. $7 \mathrm{~g}$ ) presents a slight swelling on the lateral margin of the first endopodite segment; exopodite without swelling.

Epimeral plates (fig. 7f) with a small ventroposterior tooth; plates 2 and 3 with 1 subventral spinule and 1 posterior setule.

Uropod 1 (fig. 7h): Pedunculus slender, with a strong subbasal spine; exopodite slightly shorter than the endopodite. Endopodite with 1 marginal spine.

Uropod 2 (fig. 7i) with a row of 1 longer and 3 smaller spines at the base of the endopodite. Endopodite with 1 or 2, exopodite with 0 or 1 marginal spines.

Uropod 3 (figs. 7j, k, l) slightly more elongate in adult males than in females and juveniles. Exopodite segment 1 with 2 or 3 groups of spines on each margin; outer margin moreover with a plumose seta in each group; second exopodite segment slender, tapering, twice longer than the distal spines on exopodite segment 1 , its length between $1 / 4$ and $2 / 5$ of the length of exopodite segment 1. Endopodite short, especially in younger specimens (fig. $7 \mathrm{j}$ ), between $1 / 4$ and $2 / 5$ of the length of exopodite segment 1 , pointed, armed with 1 or 2 spines and 1 setule.

Telson (fig. $5 \mathrm{~g}$ ) completely cleft; each lobe with convex lateral and straight medial margin; armature limited to 3 distal spines and 1 pair of sensory setae.

Remarks. - By the structure of the male third pleopod and of the third uropod $\left(O^{\circ}, Q\right)$, the present species belongs to the nicholsoni group of the genus Metaniphargus. It differs from all members of the genus, except for the two new Jamaican species described in this report, by the low number (8-11) of setae on the inner lobe of maxilla 1.

From $M$. craterensis the new species differs in a much shorter and less elaborately armed endopodite of uropod 3, by the downward sloping tip of the antennal cone, by the absence of additional setae on the claws of the posterior pereiopods, by the presence of a small tooth on the posterodistal corner of the basis of these pereiopods, by the presence of spinules (instead of setules) on the posterior margin of the basis of P5 to P7, etc.

Differences with $M$. anchihalinus are enumerated under that species.

Habitat. - This is the first hyporheic Metaniphargus that comes to my knowledge. The remaining species of the genus (see Stock, in press) are inhabitants of caves, springs, and wells, mostly of an oligohaline or mesohaline nature.

Metaniphargus anchihalinus n. sp. Fig. 8.

Material. - One ơ (holotype), one \& (allotype), twelve paratypes. Amsterdam Expeditions to the West Indian Islands, sta. 82-118: Jamaica, Parish of St. Ann, in an anchihaline cleft in the lowest limestone terrace near the pumphouse of the University of the West Indies Marine Laboratory $\left(18^{\circ} 27^{\prime} 28^{\prime \prime} \mathrm{N} 77^{\circ} 24^{\prime} 31^{\prime \prime} \mathrm{W}\right)$. The crack is filled with flaky sand, saturated with salt water; method Karaman-Chappuis, 501 of interstitial water filtered; chlorinity $25,624 \mathrm{mg} / \mathrm{l}$ (distance to the sea ca. $15 \mathrm{~m}$ ); 22 March 1982 (ZMA Amph. 107.645 a-c). Accompanying fauna: Actiniaria, Foraminifera, Oligochaeta, Polychaeta, Nematoda, Cyclopoidea, Harpacticoidea, Collembola, Japygidae (Diplura), Gastropoda.

Description. - Body length $2.2 \mathrm{~mm}$. Urosomites 1 and 3 without dorsal spines; urosomite 2 with 2 dorsolateral spines.

First antenna about $1.5 \mathrm{~mm}$ long; peduncle segments (fig. 8a) not very slender; accessory flagellum 2-segmented, slightly shorter than the first flagellum segment; flagellum 16- to 18-segmented, bearing an aesthetask from the 7 th to the penultimate segment; the aesthetask is very long, at least on the more distal segments, where it attains $90 \%$ of the length of the corresponding segment.

Second antenna similar to that of $M$. hyporheicus, with a slender, tapering antennal cone (fig. 8b), the distal tube of which is pointing obliquely downward. Flagellum 7 - or 8-segmented. 

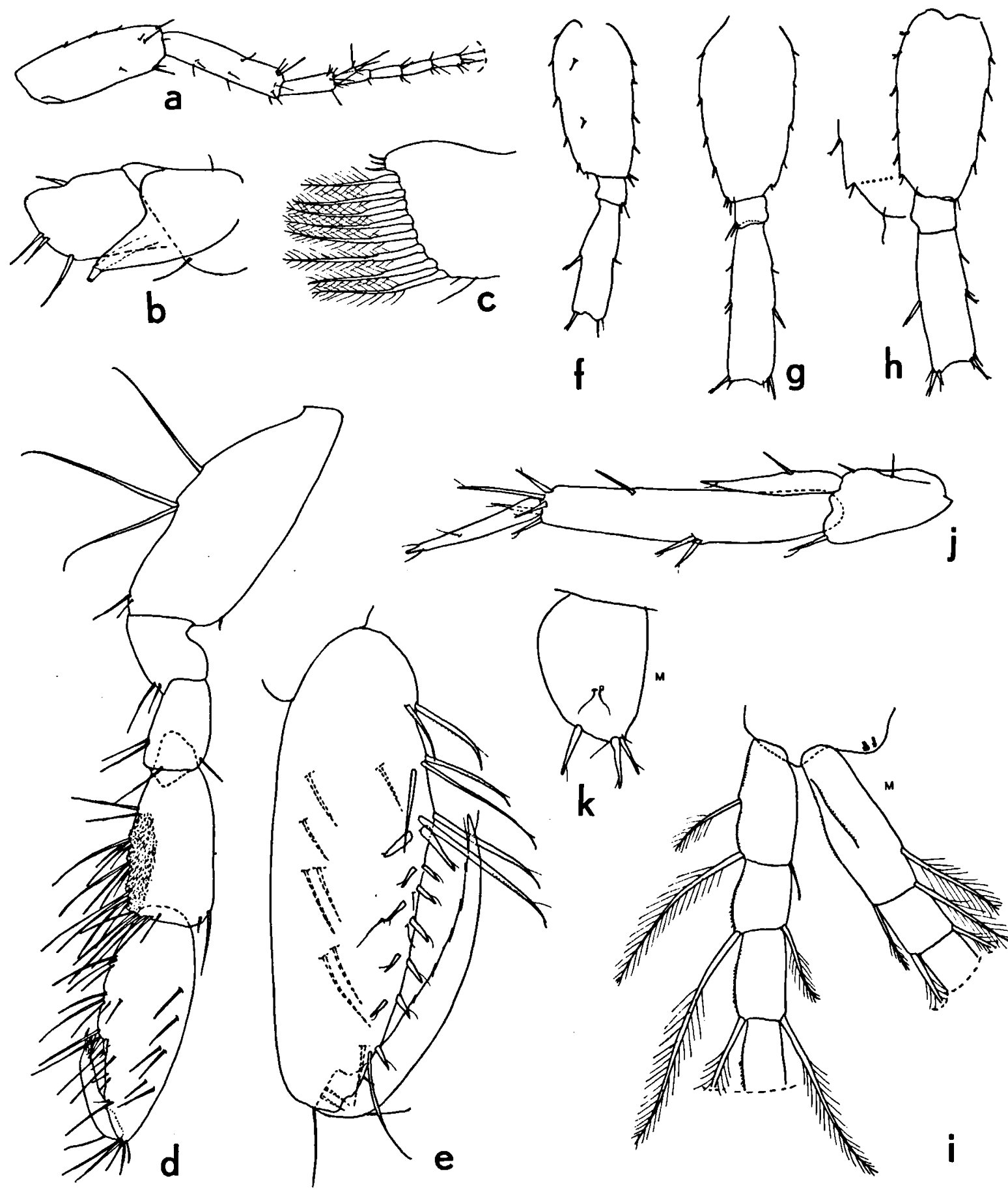

Fig. 8. Metaniphargus anchihalinus n. sp. (from sta. 82-118): a, basal portion of first antenna, $\sigma$ (scale AB); b, gland cone of second antena, $\sigma^{\circ}(\mathrm{AC})$; c, inner lobe of first maxilla, $\sigma^{\circ}(\mathrm{AE})$; d, second gnathopod, $\$$ (AC); e, propodus of second gnathopod, $\sigma^{\circ}(\mathrm{AD})$; $\mathrm{f}$, basal segments of fifth pereiopod, $\sigma^{\circ}(\mathrm{AB}) ; \mathrm{g}$, ditto of sixth pereiopod, $\sigma^{\circ}(\mathrm{AB})$; h, ditto of seventh pereiopod, $\sigma^{\circ}(\mathrm{AB})$; i, third pleopod, $\sigma$ (distal part of the rami omitted) (AD); j, third uropod, $Q$ (AC); k, telson, $Q$ (AD). $(\mathbf{M}=$ medial side of appendage.) Scales: see fig. 1. 
Mouthparts as in $M$. hyporheicus, but for the outer lobe of maxilla 1 , the distal spines of which are all multidentate; the numbers of medial teeth are $10,7,7,5,5,5,4,4,4,3$, and 4. The inner lobe of maxilla 1 bears 8 plumose setae, and 3 small, lateral spinules (fig. 8c).

The first gnathopod is similar to that of $M$. hyporheicus.

The second gnathopod (fig. 8d) has 5 groups of setae on the posterior margin of the carpus, 2 on the posterior margin of the propodus. The palm of the male (fig. 8e) has 2 long palmar angle spines, and a row of 6 pairs of palmar margin spines; the latter spines are approximately of a size, and about half as long as the angle spines. The palmar margin of the female (fig. 8d) is armed with a few setae only.

Third and fourth pereiopods similar to those of $M$. hyporheicus.

Fifth to seventh pereiopods with a very slender basis (about twice as long as wide), the posterior margin of which is armed with a limited number (4 to 5 ) of spinules only (figs. $8 f, g, h)$. The posterodistal corner of the basis is produced into a minute tooth, and is armed with a minute setule (fig. $8 \mathrm{~h}$, detail). The distal segments of P5 to P7 are lacking in all specimens at our disposal.

The epimeral plates are as in $M$. hyporheicus.

The 3rd male pleopod (fig. 8i) shows hardly any swelling on the basal segments of the rami. The first two medial setae of the exopodite are reduced in length. The basal segment of the endopodite has a chitinous, rugose crest on its ventral surface, the first lateral seta is reduced in length.

Uropods 1 and 2 resembling those of $M$. hyporheicus.

Uropod 3 (fig. 8j) with a 2-segmented exopodite; the margins of segment 1 are poorly armed with 1 group of 2 lateral spines and 1 medial spine; segment 2 is exceptionally elongate, being almost half as long as segment 1 , tapering, about twice as long as the longest distal spine on segment 1. Endopodite also tapering, lanceolate, half as long as the first exopodite segment, but much narrower; armed with 1 medial spine and 1 subdistal setule only.
Telson halves (fig. 8k) very short and wide (width/length ratio about $3 / 4$ ), armed with 1 laterodistal, and 1 or 2 distal spines.

Remarks. - This species belongs to the nicholsoni group of the genus Metaniphargus. The members of this group are distinguished by relatively minor characters only (Stock, 1977).

By the low number of setae (ca. 8) on the inner lobe of the first maxilla, the present species differs from all other Metaniphargus, except for the two Jamaican species described in the preceding pages. It differs from both by a different relative length of the endopodite of uropod 3 (shorter in $M$. hyporheicus, distinctly longer in $M$. craterensis). The very reduced armature of the margins of both uropodal exopodite segment 1 and endopodite also characterize $M$. anchihalinus. Likewise characteristic is the great elongation of exopodite segment 2 , which reaches almost half the length of segment 1 .

The downward sloping tip of the antennal cone resembles the situation found in $M$. hyporheicus. However, several small additional differences between hyporheicus and anchihalinus are present: the palmar margin spines of gnathopod $2\left(O^{*}\right)$ are of a size in anchihalinus, more irregular in size in hyporheicus; the posterior margin of the basis of P5 to P7 bears fewer spinules in anchihalinus; the first exopodite segment of uropod 3 is devoid of plumose setae in anchihalinus; the armature of the distal spines of the outer lobe of the first maxilla is slightly different.

Outside Jamaica, the most closely related taxon appears to be $M$. longipes Stock, 1977, with its two subspecies (one from Aruba and one from Curaçao), which are distinguished by a less elongate shape of the basis of P5 to P7, a richer armature of the endo- and exopodite of uropod 3, and of course by a greater number of setae on the inner lobe of the first maxilla.

Habitat. - M. anchihalinus was found in a rather peculiar habitat, from which no Metaniphargus was known so far. The species lives interstitially in flaky sand found in a crack 
TABLE I

Distribution of nine character states (1-9, see text) over the various taxa of the Hadzia complex (open symbols: plesiomorphous; closed symbols: apomorphous).

\begin{tabular}{|c|c|c|c|c|c|}
\hline & Metaniphargus & Metahadzia & $\begin{array}{l}\text { "Hadzia"' } \\
\text { pachypoda }\end{array}$ & Hadzia s. str. & Liagoceradocus \\
\hline 1. Pleopod $30^{\circ}$ & $\bullet$ & $\circ$ & ?') & $\circ$ & $\left.\circ^{2}\right)$ \\
\hline 2. Uropod 3 & $\left.\bullet^{3}\right)$ & $\circ$ & $\circ$ & $\circ$ & $\circ$ \\
\hline 3. Shape telson & $\bullet$ & $\circ$ & $\circ$ & $\circ$ & $\circ$ \\
\hline 4. Coxal gills P2-P4 & - & $\circ$ & $\circ$ & $\circ$ & $\circ$ \\
\hline 5. Palma P2Q & $\bullet$ & $\circ$ & - & - & $\circ$ \\
\hline 6. Carpus P2 & $\circ$ & $\circ$ & - & $\bullet$ & - \\
\hline 7. Mandible palp & ○ & $\bullet$ & $\bullet$ & $\circ$ & $\circ$ \\
\hline 8. Pedunculus A1 & $\circ$ & $\circ$ & $\circ$ & - & $\circ$ \\
\hline 9. Carpus P1 & $\circ$ & $\circ$ & $\circ$ & - & $\circ$ \\
\hline
\end{tabular}

1) No males of this species are known.

${ }^{2}$ ) In none of the four species of Liagoceradocus known at present (see Stock, in press), secondary sexual dimorphism in the pleopods has been recorded, so it is supposed to be absent.

${ }^{3}$ ) In $M$. jamaicae almost of the magniramus (plesiomorphous) type.

of a slightly uplifted terrace consisting of fossil coral limestones. This terrace is found at 1 to $1.5 \mathrm{~m}$ above sea level at a few metres from the actual seaboard. The deep cracks in this terrace are filled with anchihaline waters and a sandy debris. The only other hadziids found so close to the seaboard are members of the genus Saliweckelia (see Stock, 1977, and Van Lieshout, 1983).

\section{TAXONOMY AT GENERIC LEVEL}

The subdivision of the Hadzia complex (Stock, 1977) is still a matter of considerable discussion. Since the publication of my 1977 review of the hadziid Amphipoda, the following authors have discussed the taxonomy on generic level of (part of) the hadziids: Barnard, 1977; Zimmerman \& Barnard, 1977; Pesce, 1979, 1980; Barnard \& Karaman, 1982; Ledoyer, 1982; and Ruffo, 1982.

All these authors, with the exception of Ruffo, recognize four units (genera, subgenera) within the Hadzia complex, viz. Hadzia s. str. S. Karaman, 1932; Metaniphargus Stephensen,
1933; Liagoceradocus Barnard, 1965; and Metahadzia Stock, 1977. More remotely related to these is probably the couple Dulzura Barnard, 1969 and Protohadzia Zimmerman \& Barnard, 1977. Ruffo considers Hadzia s. str. and Metaniphargus as valid subgenera of Hadzia s.l., and synonymizes Liagoceradocus and Metahadzia with Hadzia s. str.

I have reconsidered the matter, especially in the light of the various new species discovered after my 1977 treatment (34 species/subspecies belonging to the six units mentioned above are known at present). The results of my comparisons are presented in table $I$ and in the cladogram of fig. 9 .

Discussion of the character states (see also table I)

1. Pleopod $3 \sigma^{\circ}$. In Metaniphargus this appendage shows very characteristic apomorphous modifications: the basal two exopodite segments fuse and the length of the plumose setae on the fusion complex is reduced. The fusion complex shows a medial swelling, very slightly marked in the beginning of the 
series (e.g., in Metaniphargus nicholsoni Shoemaker, 1959), but developing into a strong mediodistal lobe in the more advanced stages (e.g., in $M$. curasavicus Stephensen, 1933). The basal segment of the endopodite may participate in the formation of this complex structure, by the formation of a lateral swelling opposing the bulge of the exopodite (e.g. in M. bullipes Stock, 1980).

In the more plesiomorphous taxa, the two proximal exopodite segments of the male third pleopod remain independent and the reduction in length of the plumose setae is less marked or absent. Neither exopodite nor endopodite show any bulges.

2. Uropod 3. This appendage shows two states: the magniramus type (endopodite $\geq$ segment 1 of the exopodite, richly armed) and the variiramus $\rightarrow$ parviramus types [between which there seems to be no gap, at least in certain hypogean genera such as Metaniphargus (see Stock, 1977) or Rhipidogammarus (see Stock, 1978)], characterized by an endopodite which is (much) shorter than the first exopodite segment and bears only a reduced number of elements (usually no plumose setae). In the Hadzia complex, this difference is still more pronounced than usual, since the magniramus type of uropod shows a very wide endopodite (often wider than the exopodite, as if adapted for swimming), whereas in the varii/parviramus types, the endopodite is narrow, lanceolate to scalelike, and typically non-natatory.

Throughout the Gammaridae s.l., magniramus types are considered to be plesiomorphous (see Bousfield, 1977).

3. Shape of the telson. The plesiomorphous state is that in which the telson halves are of elongate shape (much longer than wide). In Metaniphargus the telson halves are shortened (length and width about equal, the apomorphous state).

4. The shape of the coxal gills. In the plesiomorphous state, the coxal gills are ovate, merging gradually into a basal, constricted part. Sometimes a well-demarcated basal stalk is developed, but this stalk is always short ( $<$ half the width of the corresponding coxal plate). In the apomorphous state, the basal stalk is very well developed, about as long as the width of the corresponding coxal plate, and often delimited from the coxal gill itself by a sort of articulation. For a most correct judgement of the states of the coxal gills, it is better to study those on the anterior legs (P2-P4), on which they are larger, than on the posterior legs (P5-P6).

5. Palma of $\mathrm{P} 2$ \%. In the plesiomorphous state, the male and female propodi are more or less similar in shape and armature. The palmar margin is long in both sexes (and so is the dactylus), whereas it is armed with numerous conspicuous spines, likewise in both sexes. In the apomorphous state, a stronger sexual dimorphism has been developed: the female palmar margin and dactylus are distinctly shorter than those in the male, and the row(s) of spinules on the male palmar margin have been replaced by setules in the female.

6. Carpus P2. This segment bears only marginal setation in the plesiomorphous state. In certain apomorphs, the posterior margin of the carpus is bulging, and the setation shifts to the implantation line of the bulge.

7. Distal segment of mandible palp. In the plesiomorphous state, this segment bears a single row of ventral elements (spinules or setules), the so-called D-setae. In the apomorphous state, these $\mathrm{D}$-setae have disappeared.

8. Pedunculus of first antenna. The melitidgrouping, with which the Hadzia complex is often classified, is amongst others characterized by an elongation of the peduncle segments of A1 (segment 2 generally $\geq$ segment 1 , and segment 3 several times longer than wide). This is considered the plesiomorphous state in this grouping. In the genus Hadzia s. str., the pedunculus (and incidentally the flagellum as well) shows apomorphous shortening of the segments 
(segment $2<$ segment 1 ; segment 3 hardly longer than wide). An abbreviation of this kind is rarely encountered in stygobiont Gammaridae.

9. Carpus P1. This segment has two expressions in the Hadzia complex. In Hadzia it is triangular to trapezoidal in outline, and short; it bears marginal setation only. In the other taxa, the carpus has a more elongate shape (sometimes almost linear) and is provided with several (rarely one) transverse rows of setae, located on the inner (= medial) surface of the segment. Since the latter condition is reminiscent of the situation frequently found in the supposingly "primitive" Baikal gammarids, and since elongated carpal segments are the usual condition in the less transformed posterior pereiopods, it is assumed that this represents the plesiomorphous state. The shortened, triangular carpus, with reduced armature, then represents the apomorphous condition.

I have not included in my consideration the armature of the telson halves, although Barnard and his collaborators used this character for distinction on (sub)generic level in the hadziid complex. Each half may have armature (usually spines) on its lateral margin, on its medial margin, or on both margins. The expression of this character is variable: certain species within the genus Metaniphargus lack spines on the lateral margin, others have them. Even within one single species (Metaniphargus l. longipes Stock, 1977, fig. $34 \mathrm{f}-\mathrm{h}$ ) medial spines may be present or absent. For this reason, I have decided not to use this "feeble" character for my cladistic speculations.

\section{Conclusions from the cladistic treatment}

My conclusion is that Metaniphargus is a strongly defined entity, in particular characterized by the autapomorphous states $1,2,3$, and 4. It shares one synapomorphy with Hadzia and with "Hadzia" pachypoda. The latter two share one apomorphy (state 6), but the same apomorphy is also shared by Liagoceradocus. Hadzia has two autapomorphies, viz. character states 8 and 9, which characterize it sufficiently to be maintained as a separate genus. "Hadzia" pachypoda shares its apomorphic character state 7 with Metahadzia, so that its taxonomic position remains unclear.

The genera Metahadzia and Liagoceradocus each have only one apomorphous (and hence 8 plesiomorphous) character states. Moreover, the apomorphous state 7 of Metahadzia is shared by "Hadzia" pachypoda and the apomorphous state 6 of Liagoceradocus is shared with the Hadzial" Hadzia" pachypoda cluster.

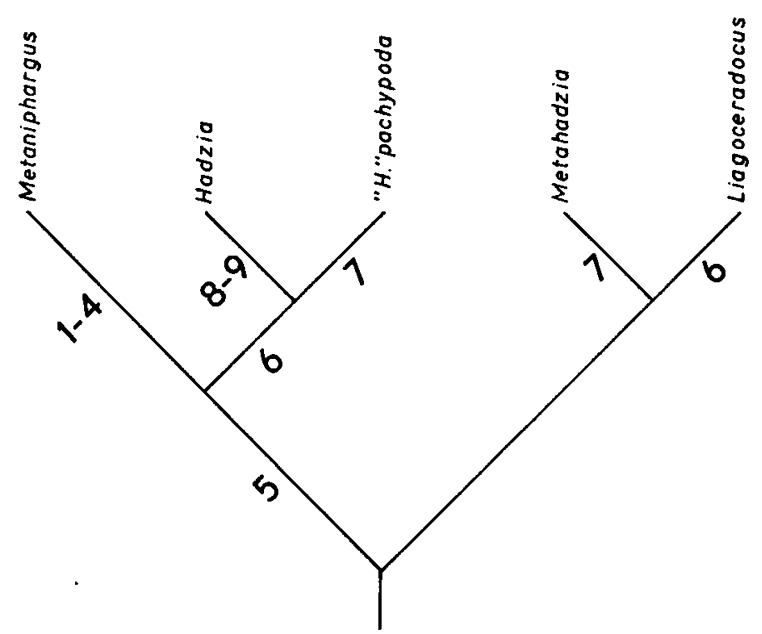

Fig. 9. Cladogram of the entities on (sub)generic level of the Hadzia complex, based on nine character states (see table I). The genera with the greatest number of apomorphies are found in the left part of the cladogram, those with the greatest number of plesiomorphies in the right. The cladogram presented here has the best parsimony, i.e. the lowest number of branching points (viz., four) and the lowest number of internal parallelisms (viz., two, in character states 6 and 7). The presumed ancestral group is plesiomorphous in all nine character states. Changes of a plesiomorphous state into an apomorphous state are indicated on each branch by the running number of the character state involved.

Although Metahadzia and Liagoceradocus are then, from a cladistic point of view, weakly characterized, there can be little doubt that these units are very clearly distinct from the Metaniphargus/Hadzia group, which has a good number of apomorphous characters to define it clearly. 
The taxonomic position of "Hadzia" pachypoda Ruffo, 1982 (a species from continental groundwaters of Somalia) must remain undecided for the moment. It is only known from females, and we have to await the discovery of males to see if its characters (in particular in the third pleopod) shed more light on the question.

The five entities recognized in the cladogram (fig. 9) are also coherent in a biogeographical and in an ecological sense, with one exception. Metaniphargus is endemic to the peri-caribbean region, and inhabits inland waters of fresh and mixohaline nature. Hadzia and Metahadzia are peri-mediterranean taxa, found in mixohaline waters. Liagoceradocus is a tropical, anchihaline to marine genus, and "Hadzia" pachypoda is known from freshwater wells in Africa (Somalia). The only exception is formed by a species described as Eriopisa laakona by Barnard, 1970, a marine species from Oahu (Hawaii), known from a single specimen only, doubtfully referred to as a male in the original description. In my opinion, the second gnathopod of this species (as illustrated by Barnard, fig. $86 \mathrm{~d}$ ) is clearly of feminine morphology (dactylus short, palmar margin armed with setules only). At any rate, all known morphological characters agree closely with those of the genus Metaniphargus, but its occurrence outside the peri-caribbean region and in a marine habitat are disconcerting. Here again, we will have to wait for the discovery of the hitherto unknown male, to see if it shows identical apomorphous developments, in particular in pleopod 3, as in typical Metaniphargus.

\section{ACKNOWLEDGEMENTS}

The fieldwork in Jamaica has been financially supported by the Beijerinck-Popping Fonds (Amsterdam), the Treub Maatschappij (Utrecht), and the Amsterdamse Universiteits Vereniging (Amsterdam).

The 1979 fieldwork has been executed by L. Botosaneanu, J. G. M. Notenboom, J. H. Stock and E. S. W. Weinberg. The 1982 fieldwork was carried out by J. H. Stock and M. Stock.

During the 1979 fieldwork, logistic support of H. M. Embassy of The Netherlands (Kingston, Jamaica) is gratefully acknowledged.
During the 1982 fieldwork, the University of the West Indies Marine Laboratory (Discovery Bay, Jamaica) served as base. The hospitality and assistance of its staff has been greatly appreciated.

\section{REFERENCES}

Barnard, J. L., 1965. Marine Amphipoda of atolls in Micronesia. Proc. U.S. natn. Mus., 117 (3516): 459-552.

- , 1969. Gammaridean Amphipoda of the rocky intertidal of California: Monterey Bay to La Jolla. Bull. U.S. natn. Mus., 258: i-x, 1-230.

-, 1970 . Sublittoral Gammaridea (Amphipoda) of the Hawaii Islands. Smithson. Contr. Zool., 34: i-vi, 1-286.

-, 1977. The cavernicolous fauna of Hawaiian lava tubes, 9. Amphipoda (Crustacea) from brackish lava ponds of Hawaii and Maui. Pacif. Insects, 17 (2-3): 267-299.

Barnard, J. L. \& G. S. Karaman, 1982. Classification revisions in gammaridean Amphipoda (Crustacea), 2. Proc. biol. Soc. Wash., 95 (1): 167-187.

Bousfield, E. L., 1977. A new look at the systematics of gammaroidean amphipods of the world. Crustaceana, Suppl. 4: 282-316.

Holsinger, J. R., 1974. A new cavernicolous amphipod crustacean of the genus Hadzia (Gammaridae) from Jamaica, with notes on the distribution and taxonomic status of the genus. Annls. Spéléol., 29 (4): 647-655.

Karaman, S., 1932. Beitrag zur Kenntnis der SüsswasserAmphipoden, 5. Amphipoden unterirdischer Gewässer. Prirodosl. Razpr., 2: 179-232.

Ledoyer, M., 1982. Crustacés Amphipodes Gammariens, familles des Acanthozomatidae à Gammaridae. Faune Madagascar, 59 (1): 1-598.

Lieshout, S. Van, 1983. Presence of a member of the genus Saliweckelia (Amphipoda) on Tortuga, Venezuela. Bijdr. Dierk., 53 (2): 244-246.

Pesce, G. L., 1979. A new subterranean crustacean from southern Italy, Metahadzia adriatica n. sp., with notes on Hadzia minuta Ruffo (Amphipoda, Gammaridae). Bijdr. Dierk., 49 (1): 102-108.

- 1980 . A new subterranean amphipod from Cephalonia, Greece, and taxonomic status of Metahadzia Stock 1977. Senckenberg. biol., 60 (3/4) (“1979"): 271-276.

Ruffo, S., 1982. Nuovi Anfipodi di acque sotterranee della Somalia. Monitore zool. ital., (N.S.) Suppl. 17 (3): 97-113.

Stephensen, K., 1933. Fresh- and brackish-water Amphipoda from Bonaire, Curaçao and Aruba. Zool. Jb., (Syst.) 64: 415-436.

Stock, J. H., 1977. The taxonomy and zoogeography of the hadziid Amphipoda, with emphasis on the West Indian taxa. Stud. Fauna Curaçao, 55 (177): 1-130. - , 1978. A remarkably variable phreatic amphipod 
from Mallorca, Rhipidogammarus variicauda $n$. sp., in which the third uropod can assume the "parviramus" or the "variiramus" condition. Bijdr. Dierk., 48 (1): 89-95.

- 1983 . Predation as a factor influencing the occurrence and distribution of small Crustacea in West Indian groundwaters. Bijdr. Dierk., 53 (2): 233-243.
- , in press. Amphipoda Gammaridae: Melitidgrouping. In: L. Botosaneanu ed., Stygofauna mundi (E. J. Brill, Leiden).

Zimmerman, R. J. \& J. L. Barnard, 1977. A new genus of primitive marine hadziid (Amphipoda) from Bimini and Puerto Rico. Proc. biol. Soc. Wash., 89 (50): 565-580.

Received: 19 May 1983 